\title{
Russia woos lost scientists
}

\section{Minister of education and science discusses plans for rebuilding the country's research base.}

Once a scientific powerhouse, Russia is still struggling to rebuild a research system shattered by the demise of the Soviet Union in 1991 and the decade of economic hardship that followed. To speed up the recovery, the Russian government recently announced a 90-billion-rouble (US $\$ 2.8$ billion) programme aimed at strengthening universities and getting high-profile expatriate researchers to return to Russia (see Nature 464, 1257; 2010). And a conference next week in St Petersburg will gather representatives of Russia's scientific diaspora to discuss how émigrés can help to restore Russian science to its former glory. In an exclusive interview, Nature spoke to Andrei Fursenko, the minister of education and science of the Russian Federation, about how he hopes to bring the diaspora back home and boost the international standing of Russian science.

\section{What problems does Russian science face?}

The revolutionary changes that occurred in the 1990s created many problems for science, such as a dramatic decrease in funding, the decline of the scientist's social status, and a low demand for research from the economy. We think that over the past decade we have been gradually overcoming these difficulties and restoring the traditions of the Russian schools of science. Science has once again become interesting and attractive for talented young people and Russian businesses.

Russian scientists are actively collaborating with their foreign colleagues.

But there are still many obstacles. They include the archaic system for organizing Russian science, in which scientific research is often artificially separated from education. Russian science has long been isolated from global science, and as a result our scientific priorities and their support system are obsolete. Science is notorious for its paternalistic nature generally, and in our case it has been further exacerbated by its Soviet upbringing.

All these obstacles are ultimately surmountable. Furthermore, I have reason to believe that the current situation is fundamentally different from what it was five or seven years ago. It would be premature to speak about a breakthrough, but positive changes are obvious. We hope we will be able to gradually create a network of world-class research universities in our country.

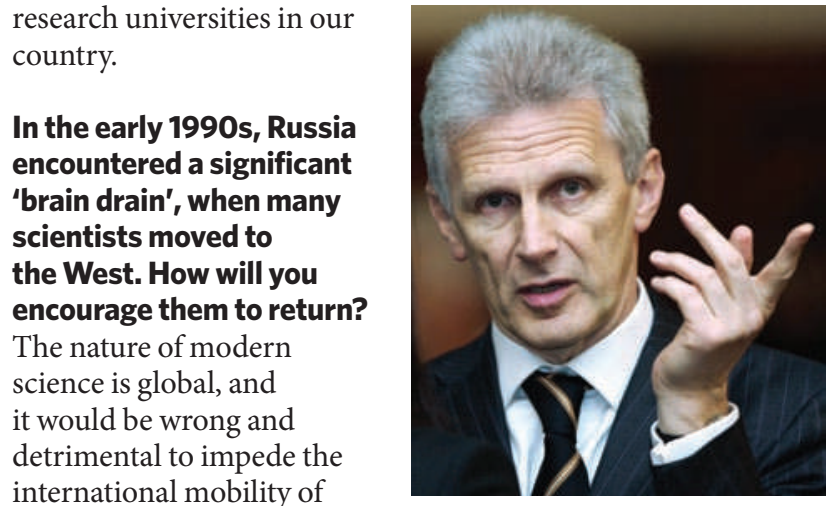

which will support scientific research projects in 2010-12, with the possibility of extending the projects for another year or two. This is not a redistribution of previously allocated science and education funding; these are new, additional funds.

Both Russian and foreign scientists are eligible for the grants. They will be awarded to scientists. For a number of reasons, however, this mobility has proven to be a one-way street for Russia. It is estimated that up to 35,000 scientists emigrated from Russia in the 1990s. Approximately the same number are still officially assigned to their respective institutions in Russia, but are in fact permanently working abroad. As a result, in many disciplines our old professors have been left without apprentices, and our young scientists have no one to learn from. These gaps should be filled not by restricting the mobility of scientists but by expanding it, and not only by encouraging our scientists to return, but also by attracting leading foreign specialists to Russia.

Last year, the government launched a federal programme, 'Scientific and pedagogical labour force for an innovative Russia, to encourage our scientists working abroad to return, take leadership of scientific teams and implement research projects in Russia. The projects were selected for federal funding on the basis of competitions, and generated a great deal of interest. The winners include our compatriots living and working in 22 foreign countries. Among them are scientists, university professors and the heads of laboratories of some leading universities and research centres in the United States, Germany and Great Britain.

The government has allocated 12 billion roubles to attract world-class scientists to Russian universities. How will that money be distributed?

The money will come from the federal budget over the next three years, and will be used to fund university research. It will be made available in the form of competitive grants of up to 150 million roubles each, universities, which will then agree with the recipients - principal investigators (PIs) of international repute - the terms and conditions of the research. Applications will have to pass through peer review according to international practice. To encourage mobility, Russian PIs will be required to relocate to a university they have not worked at before, and to set up a research team involving local scientists. Each research-project team must include young scientists, as well as graduate and undergraduate university students. A maximum of $60 \%$ of the grant money can be used for salaries.

The scientific research areas will be determined, and the grant decisions made, by the Russian Federation's grant board, which consists of internationally renowned Russian scholars. I have been asked to head the board. An official request for proposals will be published on 25 June.

\section{How closely do Russian researchers} collaborate with international colleagues?

A lot depends on the personal initiative, energy and entrepreneurship of the scientist or research group. Universities in Moscow and St Petersburg tend to take a more active part in international cooperation than most of the regional universities, although those in Tomsk and Novosibirsk are increasingly showing results that are on a par with them. Our goal is to provide the entire Russian scientific community with equal opportunities to expand international links and to create partnerships that are not limited to a handful of demonstration projects at elite universities.

Interview by Quirin Schiermeier and Konstantin Severinov. 